\title{
Nikolay Stoykov's Vision about the Composer and the Universe
}

\author{
Nikolay Ivanov Stoykov \\ Faculty of Musical Folklore and Choreography, Academy of Music, Dance and Fine Arts, Plovdiv, Bulgaria \\ Email address: \\ theStoykovs@hotmail.com
}

\section{To cite this article:}

Nikolay Ivanov Stoykov. Nikolay Stoykov's Vision about the Composer and the Universe. International Journal of Literature and Arts. Special Issue: Musical Theory, Psychology, Pedagogy and Performing. Vol. 3, No. 5-1, 2015, pp. 43-49. doi: 10.11648/j.ijla.s.2015030501.16

\begin{abstract}
I perceive it as an inward wave, a force leading me to a particular point. Starting my work sited by the grand piano, when everything else around disappears and only the electric bulb is glimmering hypothetically, I know and I am pretty sure that I am on the right path and something beautiful is going to beget! There is another crunch moment for me as a composer constant meetings with numberless folklore untapped talents I have taught. They brought me their visceral natural perception and in a practical manner had shown me the real path every Bulgarian composer must follow. Happily this coincided with my first acquaintance with Bulgarian folklore with its universe vibes, uniqueness and direct link with the contemporary music flow, leaving academism and dry theories behind. I found there my true path my professional path should goes, because Bulgarian folklore is for me a versatile source of ideas and a strong base of my style. Man has high respect by the man-creator-peoplelink and the historic destiny of this nation. A folklore expedition comes back with about 120000 distinct songs and melodies here vs 50-60 in other European countries. The aesthetic value of this art is unique and it does not have even a single template.
\end{abstract}

Keywords: Composer, Bulgarian Folklore, Chamber Music, Choral Music, Piano Music, Works for Symphony Orchestra

\section{Introduction}

Nikolay Stoykov graduated composition taught by Professor Pancho Vladigerov at the State Academy of Music in 1971. He specialised at the Moscow Conservatoire with professors Yury Holopov, E. Denisov and Dmitri Shostakovich. Since 1972, he has been appointed as a lecturer at the Academy of Music and Dance Arts in Plovdiv. In 1976, he founded the course Musical Folklore Instruments and Singing, and he is still its doyen. He has written 15 handbooks for the needs of the course including folksong arrangements, chamber, and symphonic music. Currently, he is the Harmony, Composition, and Orchestration Professor at the Academy of Music, Dance and Fine Arts.

His works include symphonic, chamber, and choral music and are often performed in Belgium, the Czech Republic, Germany, the Netherlands, Poland, Russia, the UK, Japan, etc. With the choral songs "Kalugeirne" (Hey, Nun - figure № 3) and "Gadulka Lesson” (figure № 4), a series of Bulgarian choral ensembles won 30 awards at international competitions for singing. Among them are the Tallinn festival (1975), Cork, Ireland (1976), Llangollen UK (1976), the Bella Bartok Festival in Hungary (1979), the Autumn in
Warsaw Festival (1981), the Festival in Arezzo, Italy (1982), etc. The Plovdiv Prize for Music has been awarded to him twice (1972, 1997). In 1996, he chaired a jury at the international Piano Duo Competition in Tokyo. His works were released on LPs and CDs.

\section{Works}

For symphony orchestra:

Paraphrases:

1. The Quick One (1977)

2. Overplaying for two saxophones and orchestra (1988)

3. Capriccioso for flute, violonchelo and orchestra (1998)

4. (1999), Piano Concerto(1990)

Chamber Music:

Dityrambs for percussion (1979), Two serenade for clarinet, piano and percussion (1972).

Sonatas for: violin and piano 1 (1974), 2 (1997), flute and piano (1975-76), two violoncellos (1978-81), clarinet and piano (1983), violoncello solo(1990), harp and piano (1995).

Book of the Performer pieces for solo instruments in two volumes (1972-1990).

For piano:

Preludes - two piano albums (1980-90), The Old Album 
for two pianos (1982-87), Bulgarian Dances - three piano albums for four hands (1990, 92, 93).

Choral Music:

For children's choir:

Shturche-svirche (Cricket-curlew) - cycle (1969-90), Divertimento 1 Ala-bala-nitza for children's choir and percussion (1978).

\section{Historical Origin of My Art}

My art comes from Byzantium's morose hallways, Ioan “Angelvoiced" Kukuzel's chants, with sweet-smelling church candles and blinking flamelets; it passes through fourths and fifths genesis, through countless moods, macams, tone orders and the combination between $9 / 16,11 / 16,15 / 16$ measures and visceral rough instrumental timbre that set off the human lamento voice in the line of ancient melodies... Starting there, it touches the teasingly pleasurabe metropolitan songs with a hot verse, street-organs with tinklers, clanging team of horses, music boxes and clocks, the unique "alafranga" sounds, the "kokon"s beauty ending up with muezzin's singing, and the frantic Bulgarian rhythms played by folk orchestras. Then it continues with Dobry Christov's effective choir art, Dimitar Nenov's bitonal harmonies and his folklore findings, Scriabin's affinity in piano scaffold, unveiling a new fingering ordering his invention. I arrive in the base of the "Big Mountain" by Pancho Vladigerov famous with his proud Bulgarian harmonies: the "Vardar Rhapsody", the outstanding Romanian dances, meandering in his violin concertos and his hopeless Jewish Poem. And the awe of his piano arts, last the most. This is a new brighter Ravel's harmony. But look at his impressive orchestra "tutti" and what the GP say! Have you ever heard such an expressive silence? And Konstantin Iliev's art findings, Lazar Nikolov's frenetic compositions... And last but not least Diko Iliev, this author having an invention close to Dvorak, with his melodies where the Bulgarian soul is living!
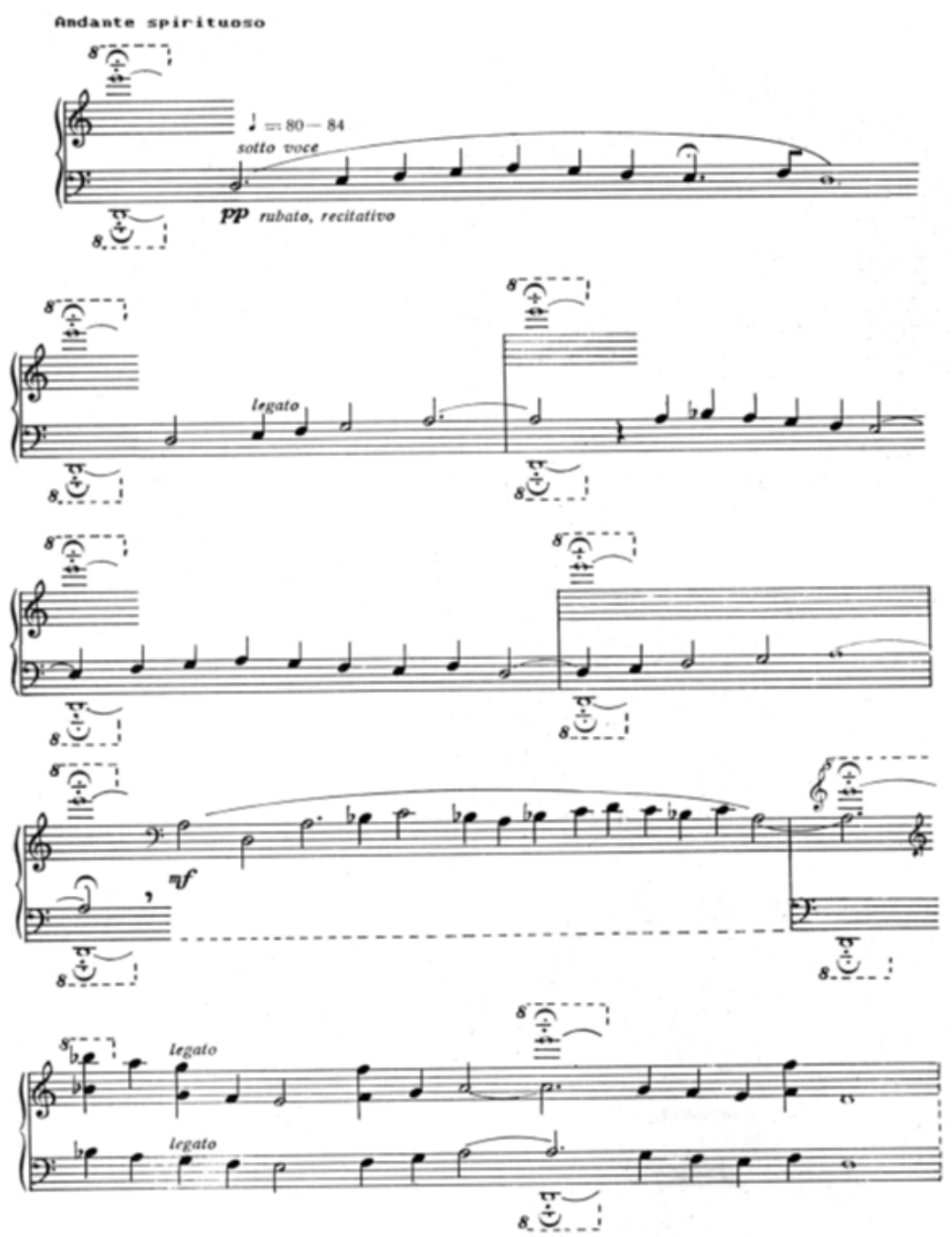

Figure No.1. N. Stoykov - “The Angelvoiced” (,Ангелогласният“) - a song for mixed choir.

We find in the original source the art pieces "Zlatyu Zlatyu", "Katunari" by Pencho Slaveykov, Renaissance 
works by Nikolay Rainov, and our Liberation poets' joyful verse. Also Yavorov, Liliev and the unique pages by Radichkov's cosmogony. All of these are deeply inside of me and give result through my personality. I perceive it as an inward wave, a force leading me to a particular point.
Starting my work sited by the grand piano, when everything else around disappears and only the electric bulb is glimmering hypothetically, I know and I am pretty sure that I am on the right path and something beautiful is going to beget!
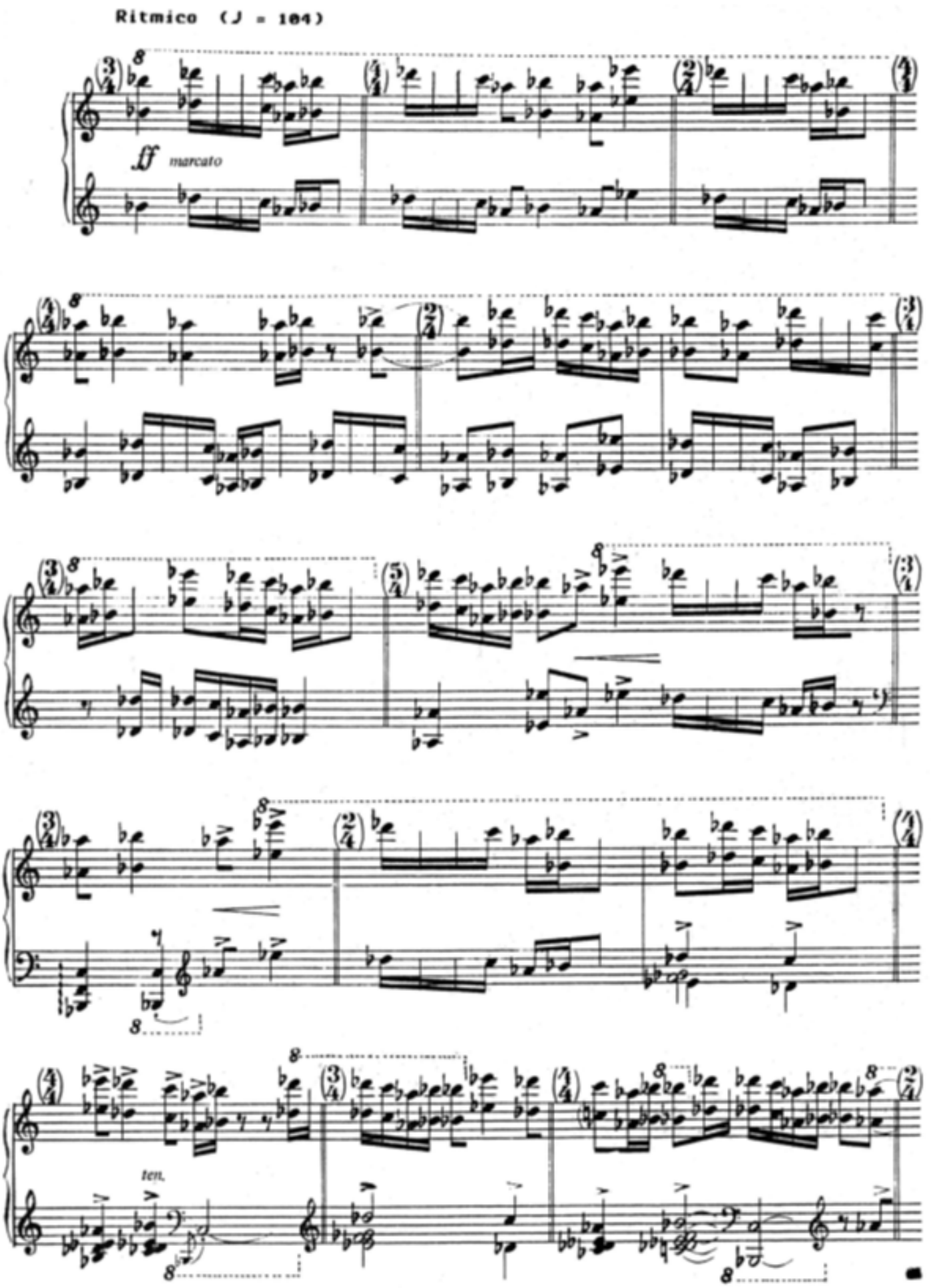

Figure No.2. N. Stoykov - "Saint George kills the Dragon” (,,Свети Георги убива ламята“) - а prelude for piano.

There is another crunch moment for me as a composer constant meetings with numberless folklore untapped talents I have taught. They brought me their visceral natural perception and in a practical manner had shown me the real path every Bulgarian composer must follow. Happily this coincided with my first acquaintance with Bulgarian folklore 
with its universe vibes, uniqueness and direct link with the contemporary music flow, leaving academism and dry theories behind. I found there my true path my professional path should goes, because Bulgarian folklore is for me a versatile source of ideas and a strong base of my style. I found that a great part of stylish directions in XX century's contemporary music had been encoded in its basics into Bulgarian folklore. Here are the main three of them: prevalent of the melody over harmony with dissonance, union of horizontal with vertical, and the mode. These are also some of the features of Second Viennese School, aren't they? While European composers found out lopsided rhythms by speculation, these had been a game, organically interweaved, spontaneously implemented into national traditions. This is why Bella Bartok calls them Bulgarian rhythms - the extempore, directly corresponding with the jazz styles. All of those modes, sound orders, diaphone, that had transformed contemporary music have been existing for centuries in Bulgarian folklore!

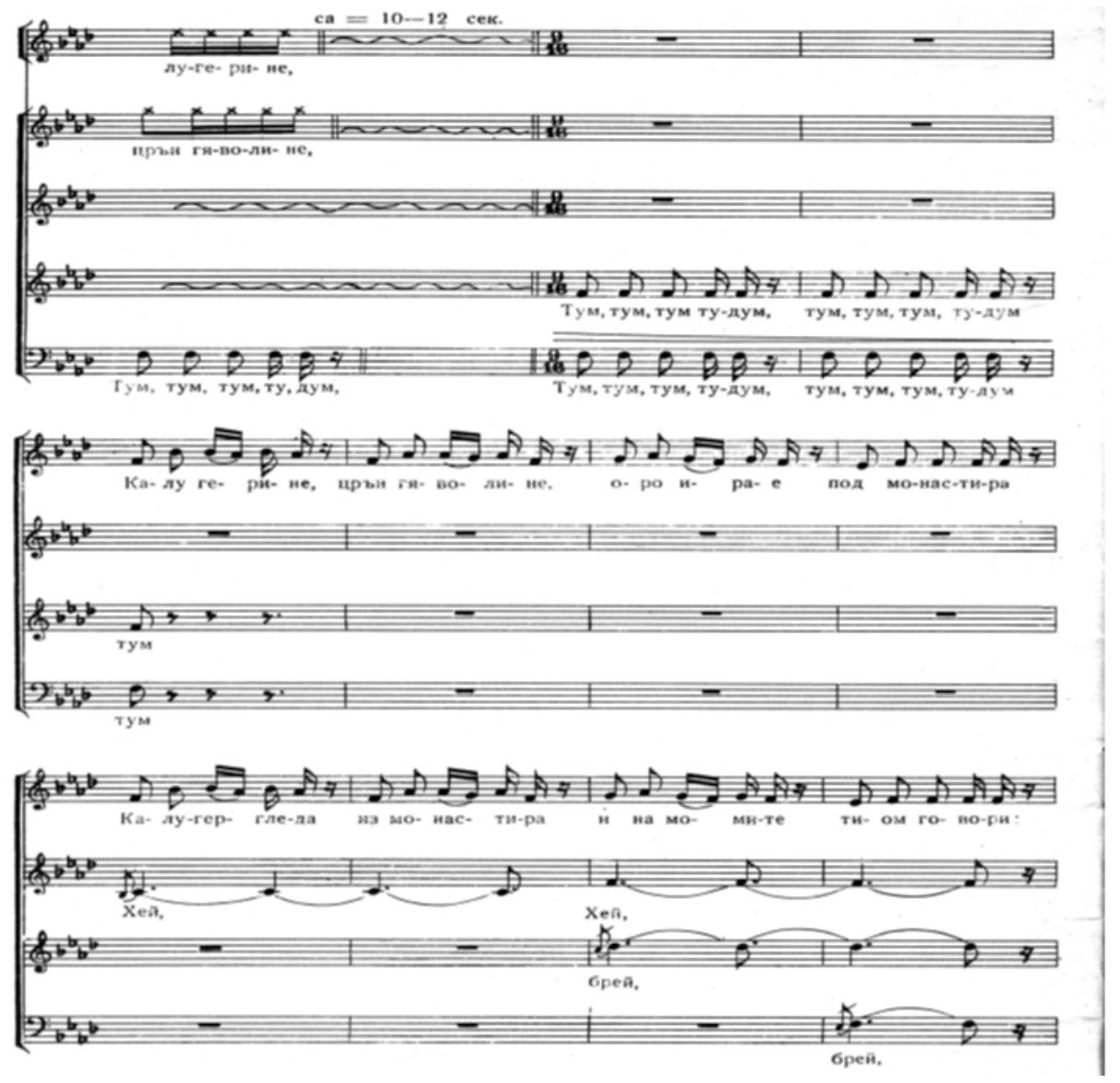

Figure No.3. N. Stoykov - “Неу, Nun” (,,Калугерине“) - a song for mixed choir.

Let's take our unmeasured songs. Their ground is the complex art of improvisation, virtuoso ornamentation, skilled breathing and the right sense for quarter intervals. Its base points - ornamentation, peaks and valleys - show direct analogy with the melody principals into contemporary music alongside with elements of accidence in the aleatoric composition practice and performance. Its graph equivalent has clear parallel with contemporary music writing. Bella Bartok compares folklore composer with the nature of a painter. I think that a composer should suffer with the folklore, otherwise it will swamp him!

If we make an in-depth analysis back in time and music history, we'll see that the national music is permeated in the art of the greatest authors and musical giants. It is impossible to create without being closely liaised with the nation agitation, feelings, and language. A creative redefinition of folklore is required. Vasil Stoin, a Renaissance man, had singlehandedly recorded thousands of thousands of melodies with verses, travelling alone with his donkey. This is a unique phenomenon over our land. This had happened when folklore expeditions all over Western Europe hardly gather some whit here and there. We can only admire our singers and players who achieved uniqueness in their improvisation. These, coming from the mother's core, live in our national musical gift and create great art and give the bases of the nation. I was gifted to touch these talents and be persuaded where my path as an author is. Otherwise I should probably dive into pseudo aesthetic music theories destroying creator's talent and keeping him away from the audience. And author without audience assessment and acceptance is a mission impossible! 


\section{About the Folklore}

This magic word "folklore" is deeply implied into each Bulgarian although some insist that at the end of XX century, it has been already shelved; others believe this very word is very useful for speculation, and still, others treat it like an elite coat. There are festivals, competitions, magazines, articles, architecture projects built over this ancient treasury. However, we still cannot touch the magic core of this word, to decode it and find its inner contents. Neither can we suitably frame it. Everyone persistently is trying to understand it, find a ground in it, accept or reject it or fight for it. These are perpetuate vibes keeping people standing. Greek writer Nikos Kazantzakis, held as a prisoner during $2^{\text {nd }}$ World War, was offered escape under the condition that he asks for mercy on his kneel. His answer was that 2000 years has been required for mankind to erect on its feet and now he has not the right to go down on his knees again! This upwardness is for me the Folklore. Man has high respect by the man-creator-people-link and the historic destiny of this nation. A folklore expedition comes back with about 120000 distinct songs and melodies here vs 50-60 in other European countries. The aesthetic value of this art is unique and it does not have even a single template.

\section{About the Choir Music}

Most of the songs of mine are a-Capella and others are with accompaniment which appears under the stress of my inward perception and necessity for timbre and dramaturgical expansion. We have to count very well the fact that the chord, played by piano does not sound the same way as performed by a choir. The composer, writing a song, must think more about an amateur choir which will facilitate the performance. My suggestion is to turn attention more on the vertical, versification, the octave position of a particular part, to think about how the culmination will be achieved, and correctness of the text, about the orthography, which should be sharp and clear. The focus is not on how "beautifully written" and pseudo respectful it is, without any affectation and premeditation. Any effects must be fine-tuned. The Medieval Great Masters of the a-Capella choir art should be heard all the time. Almost all of my songs use folk verses. The reason is I found in them great logic and clarification not available in the authorial verses.
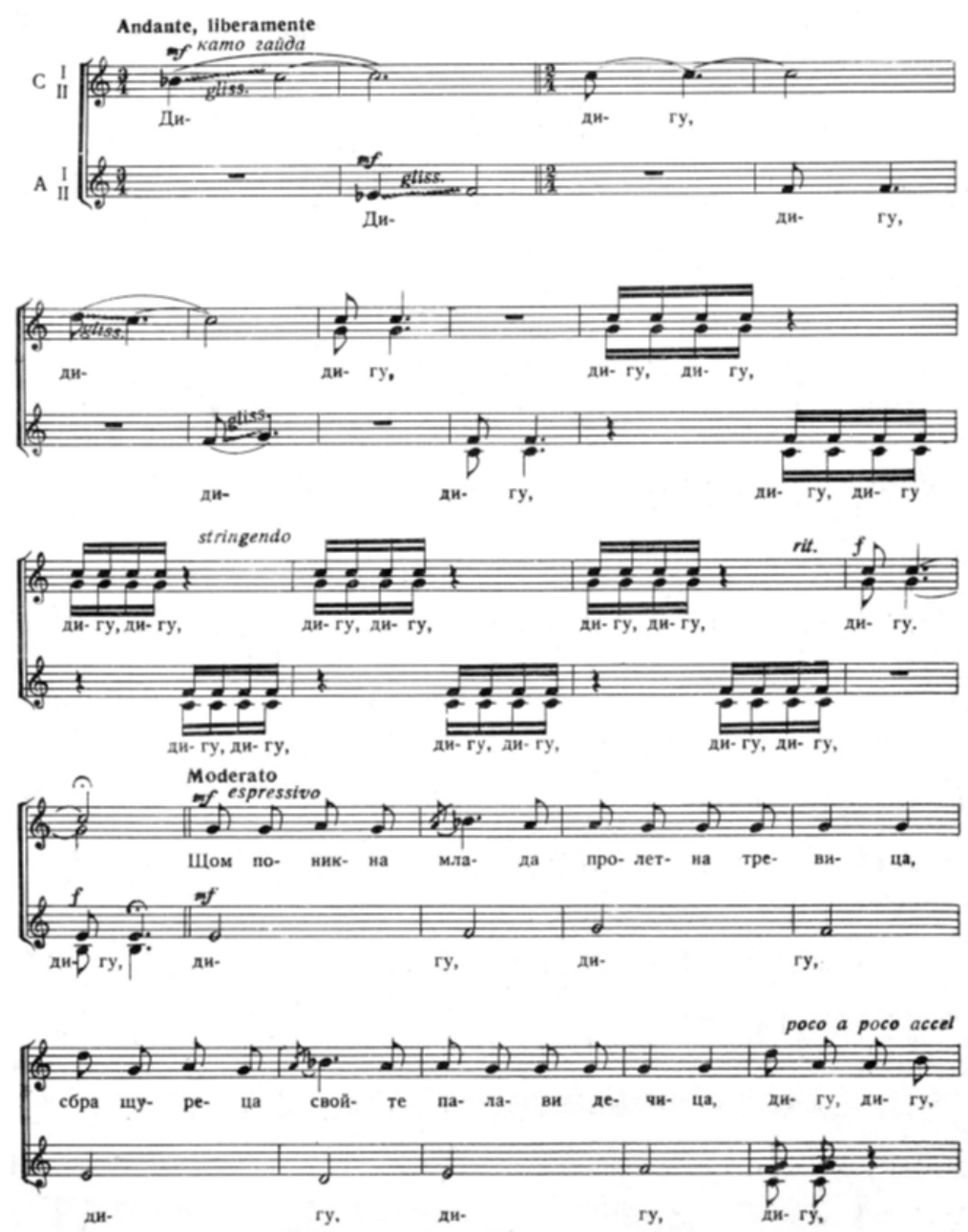

Figure No.4. N. Stoykov - “Gadulka lesson” (,, Урок погъдулка“) - a song for mixed choir.

I have creative activity as long as three quitters of the century behind me. I feel neither young nor old. The only 
harassment I have is that the given time won't be enough for the activity I've been born for - to create art inspired by birds' songs, trees' rustle, the illustriousness of national gateway, the human glory and degradation..., to achieve unity with folklore philosophy, to touch to the Universe intellect, the art of Joan Kukusel, minor Mozart's works, sad Debelyanov's verse...!
I am satisfied by the hues and the theatre grounds implied into the chamber works of mine. The timbre palette is perhaps an impulsive answer to each colour and sound. The life, having its own rhythm and organization, ringing and echoing, full of colours and sounds, creates vibes around us. Something we cannot fully explain and which we feel as an imperious force.

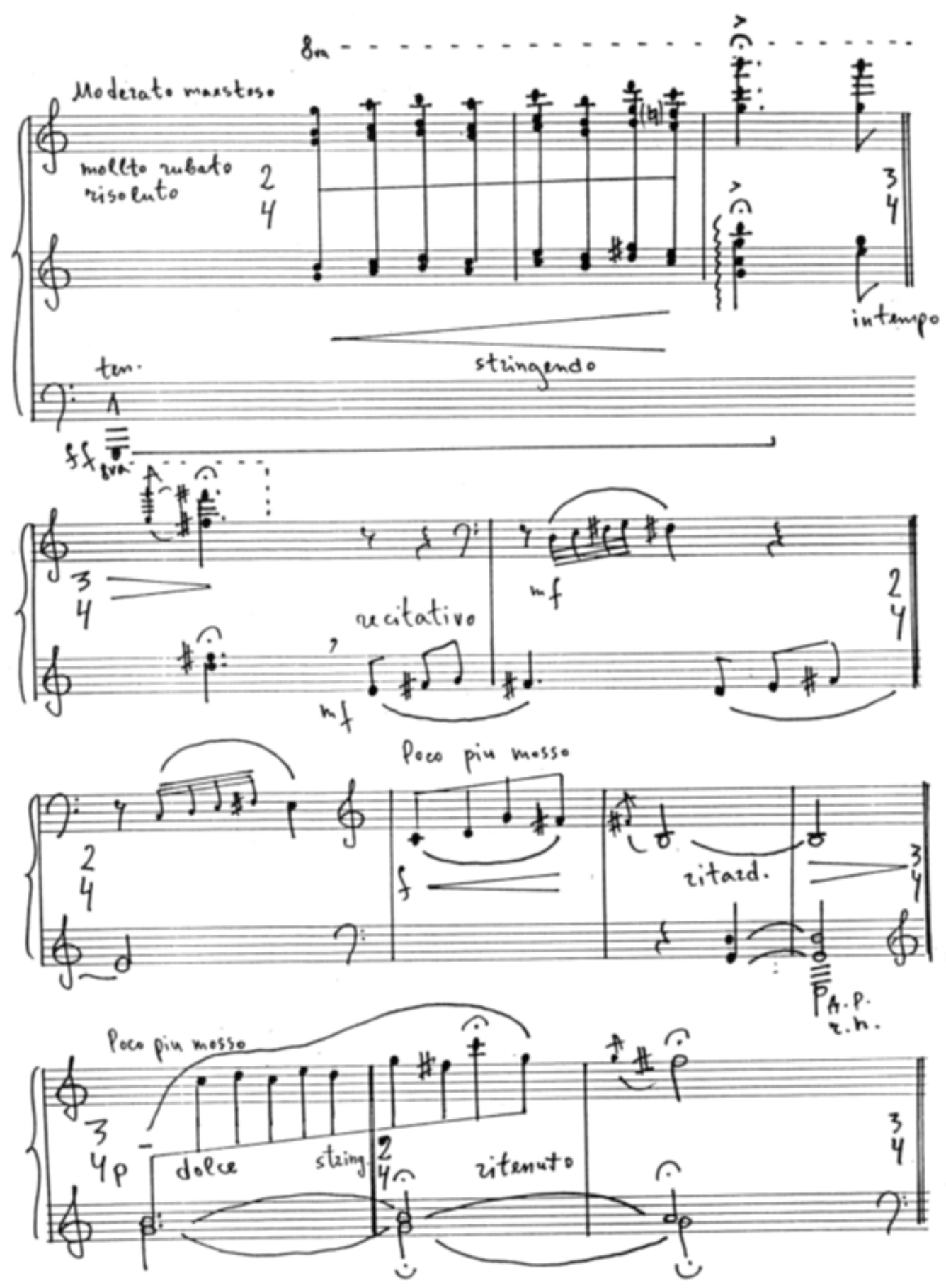

Figure No.5. N. Stoykov - "Chdrly the Great” ("Великият Чарли") a prelude for piano.

I am glad I've successfully combined folklore with contemporary techniques in the music of XX century. I am honoured to be in touch with great Bulgarian folk musicians.

\section{Conclusion}

French composer Arthur Honegger said "the music 
composition is the eeriest art." I can add that this is a peculiar puzzle that is hard to arrange because it is ordered by The Sovereign veiling many paradoxes, properties, peaks, and valleys.

\section{References}

[1] Buradzhiev, K. Nikolay Stoykov. Composers in Plovdiv and Bulgariain music folklore. Plovdiv, 2011 (Бураджиев, К. Николай Стойков. В: Пловдивските композитори и българският музикален фолклор. Пловдив, 2011)

[2] Galabov, Zdr. Plovdiv's faces. Plovdiv, 2007 (Гълъбов, Здр. Лицата на Пловдив. Пловдив, 2007)

[3] Gaytandziev, G. Alexzander Krastev. Sofia, 1962 (Гайтанджиев, Г. Александър Кръстев. София, 1962)

[4] Hristov, D. The monody in composition invetions today. Sofia, 2005 (Христов, Д. Монодията в композиторските инвенции днес. София, 2005)
[5] Kouhjumdzhiev, U. Original presence in contemporary music. Plovdiv, 1986 (Куюмджиев, Ю. Оригинално присьствие в съвременната музика. Пловдив, 1986)

[6] Krastev, A. Historical progress in music education. Sofia, 1921 (Крьстев, Ал. Исторически развой на обучението по музика. София, 1921)

[7] Palieva, A. Homo musicus (Between the Balkans and Europe). Sofia, 2006 (Палиева, A. Homo musicus (между Балканите и Европа). София, 2006)

[8] Stohyn, W. Folklore songs from Western lands. Sofia, 1959 (Стоин, В. Народни песни от Западните покрайнини. София, 1959)

[9] Stohyn, W. Folklore songs from Middle North Bulgaria. Sofia, 1932 (Стоин, В. Народни песни от Средна Северна България. София, 1932)

[10] Vassilev, M. Bulgarian folklore instruments orchestra. Plovdiv, 2009 (Василев, М. Оркестърът от български народни инструменти. Пловдив, 2009) 